Journal of Arts \& Communities

danielle Child

Manchester Metropolitan University

\title{
The artist as project manager: Thomas hirschhorn's Bataille Monument (2002)
}

\section{absTraCT}

The nature of neo-liberal management theory, based on the artist as a model worker, has proven problematic for theorizing and analysing contemporary socially engaged artistic practices. In the past, these practices were considered to be hostile to capitalism but now, with the rise of project-driven work within mainstream business models, how can we understand the socially engaged artist's relationship to capitalism? The project, the network and communication have become key attributes within neo-liberal management discourse. In this article it is argued that a certain type of artistic practice has accompanied neo-liberalism that borrows these specific tropes akin to project management. It makes connections between Luc Boltanski and Eve Chiapello's exploration of these ideological tropes in The New Spirit of Capitalism ([1999] 2007) and neo-liberal management ideas manifest in the Creative Industries in Britain. This analysis provides the theoretical base for examining Thomas Hirschhorn's role as a 'project manager' within the Bataille Monument (2002) project in the second half of the article. It is argued here that Hirschhorn retains his anti-capitalist leanings whilst also adopting neo-liberal management tropes in the articulation and execution of his project.

\section{Keywords}

Thomas Hirschhorn project management monument neo-liberalism socially engaged art 
1. The UK Creative Industries refer to the following: Advertising; Architecture; Arts and Antiques; Crafts; Design; Designer Fashion; Film; Music; Performing Arts; Publishing; Software and Computer Services; Television and Radio; and Video and Computer Games (these are the 2001 revised categories).

2. My understanding of 'project manager' for this analysis is that of a generic role; someone who manages a project from conception through to completion, including budget, staffing, communication, etc.

3. Luc Boltanski is a professor of social sciences at École des hautes études en sciences sociales, Paris and Eve Chiapello is a professor at the HEC School of Management, Paris. This dual background of sociology and management studies forms the basis of their analysis.

\section{IntroductIon}

Since the advent of neo-liberalism - the economic model that accompanied Margaret Thatcher and Ronald Reagan's respective leadership of Britain and America in the late 1970s through to the 1980s - there has emerged a new model of worker. This worker, it has been argued, is based upon the Romantic conception of the artist - a free-thinking, creative individual who is happy to work alone but also alongside others in the form of a team. These models are evidenced in the body of literature addressing the 'creative class' (Florida 2002) and the 'new bohemia' or 'neo-bohemia' (Lloyd 2006) in which it is argued that a growing class of creative types has become increasingly valuable to the economy since the 1990s. Similarly, there have been notable changes within art production in this period, which I propose have been affected by the new capitalist economic models, such as flexible accumulation that originated in the 1970s and the implementation of the Creative Industries within the United Kingdom in $1998 .{ }^{1}$ Of course, this proposition does not entail a simple mapping of the aesthetics of art onto economic models; neither is it a question of the artistic replication of contemporary working tropes - it is ideological.

This article introduces a key thesis that connects the artist to, what are contended to be here, neo-liberal ideological tropes: The New Spirit of Capitalism ([1999] 2007). These tropes can be found in the role of the project manager, which, I argue, are identifiable in certain socially engaged artistic practices, including that of Thomas Hirschhorn's 2002 Bataille Monument project. ${ }^{2}$ The first half of this article presents the historical backdrop against which Hirschhorn's project is implemented and connects the 'new spirit' ideology to a neo-liberal economy. The second half examines his project in relation to the theoretical discussions of neo-liberalism that precede it and considers Hirschhorn's practice as a form of project management.

\section{The 'new spirit' of capitalism}

In 1999, Le nouvel espirit du capitalism/The New Spirit of Capitalism was published in France, and subsequently translated into English in 2005. Boltanski and Chiapello's thesis relies upon an analysis of management discourse from the late 1960s to the 1990s for the task of illustrating the inherent changes within capitalism. $^{3}$ Because of their focus on management textbooks, Boltanski and Chiapello's analysis becomes useful for looking at the ideologies emerging through the implementation of new management models, despite their insistence that the 'new spirit' is not a superstructural phenomenon. Their assertion is a response to the restrictive 1970s notion of ideology that they are working against in their book. The 1970s notion, they argue, reduced the concept of ideology to a set of 'false ideas' (Boltanski and Chiapello [1999] 2007: xx). It becomes apparent within Boltanski and Chiapello's analysis that 'spirit' is interchangeable with a more dialectical conception of 'ideology' when they state: '[...] the spirit of capitalism not only legitimates the accumulation process; it also constrains it' (Boltanski and Chiapello [1999] 2007: xx). The understanding of ideology to which this article refers is based upon the Marxian conceptualization. The economic base (i.e. working models, such as those cited in this article) is understood to have a dialectical relationship with the 'superstructure' (law, art, politics) to which Karl Marx argues that there 'corresponds definite forms of social consciousness' (Marx [1935] 2007: 425). These forms of consciousness - ideas and beliefs - that stem from the dominant 
economic models in society are what I refer to as 'ideology'. As such, the neoliberal ideology referenced in this article is that of a flexible, networked society stemming from the economic models to be discussed.

Boltanski and Chiapello recognize that the subject of 'capitalism' was off the agenda for sociology in the 30 years preceding their analysis - being a concept that was associated with Marxism - and, therefore, they acknowledge that there was no 'wider picture' in which to observe the changes within society. This outlook provides one of the main driving forces for their analysis, which resulted in The New Spirit of Capitalism. Their thesis draws heavily on the analytical framework and model of the city in Boltanski's De la justification (Boltanski and Thévenot 1991), co-authored with Laurent Thévenot, to which I return in the analysis of Hirschhorn's project. Boltanski and Chiapello's thesis has not remained within the sphere of sociology. Its reception within contemporary art circles, particularly those concerned with art and social change, is notable. ${ }^{4}$ The appeal of the book to contemporary art theorists lies in the inherent connection that Boltanski and Chiapello identify between an ideological phenomenon within management models and the demands of the artist in the 1970s. This identification paves the way for a new model of capitalism that co-opts these demands as its own, evident since the 1990s. The shift to a participatory practice in art is often considered alongside the rise of this new model of capitalism, particularly in Europe and the United States of America.

\section{Capitalist co-optation: The two models of critique}

In The New Spirit of Capitalism, Boltanski and Chiapello present two models of critique identified within society and aimed at challenging capitalism found in management texts. These models of critique appear around moments of social and artistic change, namely the 1930s and the late 1960s. Extending this interest in specific periods, their examination focuses on the ideological effects of capitalism on management discourse. For their research, Boltanski and Chiapello looked at two corpora of management literature (from the 1960s and the 1990s) focusing on the subject of 'cadres' (in its various guises from engineer to middle-management), comprising of 60 texts each. In addition to the above two periods (the 1930s and post1968), they infer that a third 'spirit of capitalism' has come into being since the 1990s. Boltanski and Chiapello define the 'spirit of capitalism' as 'the ideology that justifies engagement in capitalism' (Boltanski and Chiapello [1999] 2007: 8). Each 'spirit' of capitalism identified within the management literature is demonstrative of how the subsequent model of management responds to each mode of critique. For example, the 1960s model legitimizes the manager whilst denouncing a more familial model of the firm; subsequently, the 1990s model works against a rigid management model to adopt a more flexible approach (Doogan 2009: 31).

The first moment of critique - 'social critique' - is identified with post-1930s and the implementation of Fordism, whilst the second, 'artist critique', occurs in the 1960s and is foregrounded in $1968 .{ }^{5}$ The social critique challenges capitalism as a source of poverty among workers, and for unprecedented inequalities (especially between the rich and the poor). It further criticizes capitalism for being a source of opportunism and egoism, which destroys collective bonds and solidarity by exclusively encouraging private interests (Boltanski and Chiapello [1999] 2007: 37). Boltanski and Chiapello propose that the model of
4. Authors engaging with their work includes Brian Holmes (2004a, 2004b) and Maria Lind (2007).

5. The model of 'social critique' that Boltanski and Chiapello work with comes from César Graña's Bohemian versus Bourgeois. French Society and the French Man of Letters in the Nineteenth Century (1964). 
6. I refer throughout to 'artist critique', rather than the sometimescited 'artistic critique', following Chiapello's preference delineated in her article 'Evolution and co-optation' (2004). Chiapello states:

Whereas many artists expressed this [artist] critique forcefully, they were not alone in doing so, which is why I prefer to speak of 'artist critique' rather than 'artistic critique' - especially since the latter is an ambiguous term liable to mean that artists are the subject of either the critique or its target.

(2004: 586, original emphasis) artist critique began to be co-opted by capitalism after $1968 .{ }^{6}$ Within the artist critique, capitalism is criticized, first, for being a source of oppression. Second, it questions the freedom and autonomy of humanity; man is now subjected to the market and capital more widely. Finally, capitalism is criticized for being a source of disenchanted goods leading to disenchanted lifestyles (Boltanski and Chiapello [1999] 2007: 37).

The model of artist critique is rooted in the invention of a bohemian lifestyle. This notion is founded upon the divide between the bourgeoisie as landowners, on the one hand, and the artists and intellectuals who are considered to be free from 'production', on the other (Boltanski and Chiapello [1999] 2007: 38). It is not only Boltanski and Chiapello who identify a parallel between bohemia and the period in which the 'new spirit' manifests - the term 'neo-bohemia', coined by Richard Lloyd (whose earlier work theorizes the rise of the 'creative class') becomes synonymous with the new economy (2006). However, I assert through my analysis of Hirschhorn's project, that the artist's divorce from production is mythological and not, in fact, the case at all. It is just a different form of production (aligned with immaterial labour in the form of ad hoc projects) in which the artist is engaged. The artist critique, Boltanski and Chiapello claim, presents itself as a 'radical challenge to the basic values and options of capitalism' (Boltanski and Chiapello [1999] 2007: 39). The personification of this type of critique thus manifests in the model of the dandy - a free-thinking, creative, flexible individual, based on the ideals of the Romantic artist. Boltanski and Chiapello identify the absorption of the model of artist critique into business models after 1968 . Thus, management discourse begins to seek qualities stemming from the critique - such as flexibility and creativity - in its employees, demonstrated in the publication of titles such as Artful Making: What Managers Need to Know About How Artists Work (Auston and Devin 2003). These qualities are drawn from the model of the artist, albeit a mythical one. Furthermore, the transparency of these qualities are made clear in documents such as England's Department of Culture, Media and Sport's (DCMS's) 2007 review of the economic performance of the Creative Industries in which the management of 'creative' people is highlighted. It states: '[...] the creative process necessarily involves marrying and integrating diverse and sometimes very individualistic people in creative teams' (The Work Foundation 2007: 20). It later states that the 'organisational challenge is to find a way of harnessing it [creativity], rather than obstructing it' (The Work Foundation 2007: 141). I will later show how these mythical qualities have a concrete effect on the contemporary artist whose work is project based.

\section{The arTisT model}

Building upon the idea of the bohemian, Boltanski and Chiapello propose that a certain conception of the artist - the Romantic artist - becomes the new model of 'worker' within the third period (c. 1990s). Maurizio Lazzarato (2007) disparages this model of artist. He argues that the idea of the artist, which Boltanski and Chiapello claim capitalism co-opts, is an out-of-date notion. Because of this proposition, the model is, therefore, not a true representation of the artist that is contemporary to the period on which Boltanski and Chiapello focus. Contrary to Lazzarato's criticism, I propose that the model of artist - which is akin to that of the Romantic artist (the creative individual, embodying divine talent, who goes against the grain, etc.) - is precisely 
the conception, or rather the stereotype, of an artist that the non-art experts surmise is an 'artist' in contemporary culture. The earlier cited DCMS report makes this clear when, with reference to management hiring creative types, it states: '[...] a culture that tolerates and embraces its deviants, heretics, eccentrics, crackpots, weirdos and good, old-fashioned original thinkers may enjoy payoffs in terms of economic performance' (The Work Foundation 2007: 141). As such, the manager or management theorists (who are not concerned with recent artistic practice) choose this mythic artist stereotype as a new ideal worker because they believe that artists are non-conforming, free-thinking individuals tied to countercultural activities. Tolerance for these types of people will pay off in the long run, as long as they can be managed. Management becomes a key issue highlighted in the DMCS report: 'Organising diversity can be problematic [...] If not managed wisely, that divergence may give way to disagreement and even conflict that eventually stifles creativity' (The Work Foundation 2007: 141).

This view is historically conditioned, originating from the artist-genius myth in which the artist is considered to be a lone creative individual who suffers from having an innate god-given talent and whose personality borders on madness (Vincent Van Gogh is a prime example of this mythology). Furthermore, one has to consider when Boltanski and Chiapello identify the artist critique as occurring. They see the critique as being 'rooted in the invention of a bohemian lifestyle' that takes the Romantic artist as its model alongside the bohemian or dandy, which was originally a modernist (bourgeois) idea born out of the nineteenth century (Boltanski and Chiapello [1999] 2007: 38). Nevertheless, the modernist notion of an artist is pertinent to their analysis and one to which we will return in relation to Hirschhorn.

\section{The 'new spiriT' of neo-liberalism}

Boltanski and Chiapello's analysis provides an ideological framework, tied to a body of 1990s management literature, in which to examine socially engaged projects that employ a project leader. However, their thesis is not without omissions. The key omission for this analysis is the inherent connection between the move to flexible, networked, creative management models and neo-liberalism; a gap that this article intends to close. Boltanski and Chiapello argue that the adoption of the artist critique allows for a new political community to emerge that is based upon networks and projects - the projective city. This city is only identified in the 1990 corpus of business literature, and thus coincides with neo-liberalism. They argue that various models of political cities coexist within contemporary society. In his analysis, Alex Callinicos simply refers to the cities as 'political communities' (2006: 64), an interpretation which I adopt. Drawing heavily upon Boltanski's earlier work with Thévenot, Boltanski and Chiapello state that each city corresponds to a distinct 'logic of justification'. Boltanski and Chiapello's spirits of capitalism are rooted in the idea of justice within the cities, in so far as models of critique are always backed up by justifications. They delineate 'high status' or a model of 'great man' for each city, which is rooted in their belief that disputes over justice always refer back to status (Boltanski and Chiapello [1999] 2007: 22-24). Thus, the great man is one who is powerful within the community and adopts an authoritative status; he is the person to turn to when a dispute arises. In the model of the projective city, the organization of society is seen to be in a project form. The status of people in this model is measured by 
activity; the more active the person, the greater the status becomes. Status, in this community, is measured by communication, reflexivity, engagement and working together (Boltanski and Chiapello [1999] 2007: 103-07). The 'great man' within this community is, essentially, the 'network man' or, as I understand it, the project manager.

Arguably, the features within business models (including the 'great man') that Boltanski and Chiapello identify as originating from the artist critique are indebted to the implementation of a neo-liberal economy. Kevin Doogan (2009) views the omission of the concept of neo-liberalism from Boltanski and Chiapello's account as a critical weakness, despite their analysis being specific to France (the two main 'neo-liberal' countries being America and Britain). Because of this caveat, the shift to flexible working models - evident in the 1990s management literature and associated with the 'third spirit' appears out of nowhere, unrelated to the state or the wider economy (Doogan 2009: 33). As I earlier articulated, the connection between economy and ideology is central to my argument. The gap between the two can be bridged by looking to analyses of neo-liberal capitalism alongside the period in which Boltanski and Chiapello claim that the third spirit manifests. In her Third Text article, Eve Chiapello (2004) refers to the period following the late 1970s, when the artist critique was subsumed into everyday business practice, as 'neo-flexible capitalism'. Elements of Boltanski and Chiapello's artist critique can also be found within the economic model that David Harvey terms 'flexible accumulation' (1990). Harvey's concept of flexible accumulation is analogous to Chiapello's neo-flexible capitalism. The two economic models share features such as worker flexibility, the encouragement of an ethos of individuality and the employment of sub-contracted labour or project-based work. In the following, I will briefly map the economic model of flexible accumulation that accompanies neo-liberalism in order to show how these tropes are connected to the 'new spirit'.

In The Condition of Postmodernity (1990), Harvey delineates the features of the economy initiated by the neo-liberal governments in both Britain and the United States, under Margaret Thatcher and Ronald Reagan, respectively. Flexible accumulation is the economic 'regime' within the post-Fordist period; as such, Fordist production methods are in decline and the move to the service industry is increasing. Harvey states that flexible accumulation directly confronts the problems that a waning Fordism posed. In particular, the rigidity enforced on the markets and the mass production systems that lead to inflexibility in design (Harvey [1990] 2008: 142). Subsequently, flexible accumulation replaces the rigidities of Fordism with flexibility; whereas Fordist production methods dictated the market in many ways, the consumer directs production under flexible accumulation. This adoption of flexibility results in the implementation of new production processes.

The idea that a product can be quickly adapted to the market pertains to another feature of flexible accumulation. Harvey argues that flexible accumulation pays attention to changing trends and 'cultural transformations', whilst also reducing the half-life of a product (the time it takes the product to 'wear out') ([1990] 2008: 156). On a visual level, Harvey suggests that flexible accumulation adopts the 'fleeting qualities of a postmodernist aesthetic' ([1990] 2008: 156). This adoption, he argues, includes the commodification of cultural forms, to which we could further add the Creative Industries. The idea of the commodification of cultural forms is insightful, helping to explain how flexible accumulation fosters an economy in which artists or creative individuals 
become valuable. Within this model, artists are no longer the critical outsiders but rather, if we accept Boltanski and Chiapello's thesis, the criticality of the artist is adopted by the new capitalist economy. Harvey writes: 'All this has put a premium on "smart" and innovative entrepreneurialism, aided and abetted by all of the accoutrements of swift, decisive and well-informed decision-making' ([1990] 2008: 157).

Arguably, flexible accumulation allows for art to be thought of as a commodity (as opposed to living in an uncommodifiable sphere of its own). The production and marketing of one-off, customized goods, all point to the commodification of something conceptually very close to art. This closeness can be seen in collaborations between artists and brands - that of Takashi Murakami and Louis Vuitton, for example. The result of this kind of collaboration is the production of a one-off or limited edition item - in the above example, an artist-designed Vuitton handbag - with a large price tag to accompany it. The imagined gap between art and commodity closes further under flexible accumulation, imagined, because of the divide that was historically drawn between high and low culture: art being the former, commodified goods belonging to the latter. Furthermore, within the art world, the advent of socially engaged practice (which avoids the production of a commodity) takes the form of the one-off, unrepeatable project that draws on the strengths of its project leader (the artist).

\section{arTisTs respond To The 'arTisT CriTique'}

So what happens to the artist once their mode of critique is co-opted by the system that they intended to criticize? The relevance of Boltanski and Chiapello's thesis lies in their articulation of a change in management discourse post-1968, which is symptomatic of wider ideological changes. It is in this period that openly collaborative practices in art became visible. The number of political artistic groupings established in New York alone during the late 1960s and early 1970s (and adopting the artist mode of critique) - such as the Art Workers Coalition (AWC), Colab and Women Artists in Revolution (WAR) - is significant. These practices began to respond to the internal changes within capitalism, such as privatization and inequality. A later return to social and collaborative practice, made visible in the 1990s, signalled a rejection of the model of artist critique, which capitalism had by then fully co-opted. Furthermore, these new practices, for the most part, adopted the terms of 'social critique' and collective labour in order to criticize the 'spirit' that accompanies the artistic critique. The artist as a free-thinking individual now belonged to capitalism. Therefore, the new avant-garde was to be found in collaborative art practices, and this remains evident in contemporary art. However, whilst responding to the adoption of the individualism of the alienated artist (i.e. the artist as an individual on the fringe of society) through a return to collectivity, later artists (such as Hirschhorn) still retain a level of 'authorship', which is rooted in the model of artistic critique. The dominance of the artist mode of critique, and its subsequent absorption into capitalism, is at the heart of the changes that Boltanski and Chiapello describe as being afoot in the 1990s. However, the distinction between the co-optation of the artist critique by capitalism and the move to collective production in art cannot be simply mapped in this way. In the following section, I will introduce Hirschhorn's anti-capitalist practice, whilst also highlighting a positive adoption of neo-liberal traits (such as the project, flexibility, temporary networks) 
7. Hirschhorn was not the first artist to site his work away from the main Documenta arena. In 1982, Joseph Beuys exited the main site of Documenta 7 to create his work 7000 Oaks. Beuys undertook a social work of a different kind, with the planting of 7000 trees - and accompanying basalt columns - as its aim. Beuys anticipated that each tree would be a 'monument'. in his Bataille Monument work. As the 'great man' in the projective city is here ascertained to be the 'project manager', I propose that Hirschhorn's practice can also be considered on these terms.

\section{The BaTaille MonuMenT (2002)}

Hirschhorn is not concerned with making saleable art objects - he often uses perishable everyday materials like cardboard, parcel tape and tinfoil. Moreover, he is an artist whose oeuvre is proliferated with installations and temporary projects that adopt anti-capitalist tendencies. Hirschhorn is critical of the effects of capitalism and has, in the past, made works about looting Chalet Lost History (2002) - and also ones that address material excess and mass consumption - Too Too - Much Much (2010). Despite Hirschhorn's critical approach to capitalism, he additionally adopts some of the traits of, what is considered to be, an ideal type of worker under neo-liberalism. In 2002, Hirschhorn created the temporary 'social' work - Bataille Monument - for 'Documenta 11' in Kassel. It exemplified the kind of work that comes under the rubric 'new genre public art' (Lacy 1995) or 'socially engaged art'; it incorporated a public audience and also participation from the community where the piece was sited. Hirschhorn's ambitions were not to produce objects but to engage a social dialogue. He states: 'The Bataille Monument demanded friendship and sociability and was intended to impart knowledge and information, to make links and create connections' (Hirschhorn 2004: 135). In his writings on the Bataille Monument, Hirschhorn repeatedly stresses the idea of the work being an experience and an opportunity for discussion. From the outset, the work can be understood in terms of the temporary project and the network. In Hirschhorn's own words:

Bataille Monument is a precarious art project of limited duration in a public space, built and maintained by the young people and other residents of a neighbourhood. Through its location, its materials and the duration of its exhibition, the Bataille Monument seeks to raise questions and to create the space and time for discussion and ideas.

(2004: 98)

Documenta 11 funded Bataille Monument, although Hirschhorn chose to situate the work away from the main site in a suburb where the majority of the population was Turkish. ${ }^{7}$ The Monument consisted of three shacks situated between two housing projects; one housed a library of books and videos around Bataillean themes with an area to view these; the other was a television studio and the final one consisted of an installation based on Bataille's life and work. There was also a snack bar and a taxi service run by locals, and a sculpture. The three latter elements were not just practical offerings. Hirschhorn had considered how to alternatively engage people in conversation through them. For example, Hirschhorn writes: 'The idea of a snack bar was not primarily about offering food and drinks, but about offering visitors the opportunity to meet, converse and spend time together' (2004: 140). The sculpture appears at the end of the list, as this seems to be, interestingly, how it is prioritized in the other literature on the Monument. Notably, Hirschhorn does not directly refer to the sculpture in his statement reproduced above. However, he does state elsewhere that: 'The sculpture was supposed to be only the sculpture of the monument and not the monument itself' (2004: 143). 
Arguably, the term 'monument' refers to a structure or object rather than a project per se. The shacks could fall under this category. However, on the level of syntax, the sculpture would be more traditionally viewed as the actual 'monument' - the public object. In an interview for October journal with Benjamin H. D. Buchloh, Hirschhorn states that he conceives of sculpture as an event or meeting place rather than an object just to be looked at; it is something in which someone participates (Buchloh 2005: 85-86). One could further interpret this definition of the monument as a project.

\section{Thomas hirsChhorn - arTisT as projeCT manager?}

Despite his anti-capitalist leanings, Hirschhorn fits comfortably within Boltanski and Chiapello's projective city. This is the city belonging to the period in which the Creative Industries were born and also one to which short-term temporal projects and networks are central. Bataille Monument epitomizes the utilization of the temporary project within contemporary art. Of course, this comparison is not so simplistic - Hirschhorn calls Bataille Monument a project, so it must belong to the 'projective city'. Art is not necessarily affected in the same ways that a business model may be. Nevertheless, it is argued here that the choice of working model adopted for the Bataille Monument was affected by the ideological implications of an economy based around networks and short-term projects, and one that welcomes the creative individual who can make it happen.

Hirschhorn's project included heterogeneous groups of participants, and vast numbers at that. Referring to the networked society, Boltanski and Chiapello write:

In a reticular world, social life is composed of a proliferation of encounters and temporary, but reactivatable connections with various groups, operated at potentially considerable social, professional, geographical and cultural distance. The project is the occasion and reason for the connection. It temporarily assembles a very disparate group of people, and presents itself as a highly activated section of network for a period of time that is relatively short, but allows for the construction of more enduring links that will be put on hold while remaining available.

([1999] 2007: 104, original emphasis)

The Monument consisted of bringing together socially diverse groups of people to work on the project. ${ }^{8}$ The shacks were built by Hirschhorn and between twenty and 30 residents from the Friedrich-Wöhler-Siedlung, where the Monument was situated. The residents of the housing estate were predominantly Turkish. This is the aspect on which the criticism of Hirschhorn's work was focused. The residents were remunerated eight euros per hour for their work. Uwe Fleckner, an art historian, assisted in choosing the categories and selecting books for the library. The French writer and art critic, Jean-Charles Massera; French poet, Manuel Joseph and the German philosopher, Marcus Steinweg, were each invited to hold workshops at the Monument. Massera worked with the young people to perform his texts; Joseph forged ten letters titled 'Sculpture as a bullfight', which were disseminated to almost 100,000 Kassel households, whilst Steinweg's workshop focused on the production of texts that contributed to an exhibition panel on The Ontological Cinema. There were also the local residents who manned the snack bar (and kept the
8. A full description of the project can be found in Hirschhorn (2004). 
profits) - the Kaban family - and the five drivers who ran the shuttle service to and from the Monument. Furthermore, Hirschhorn consulted the poet Christophe Fiat in his research on Bataille's work in preparation for Documenta 11. The visitors who made the journey from the main site of Documenta 11 to the Monument should not be excluded from this status. In addition, there were webcams that were set up for worldwide access to the Monument and the people who accessed these. Without extending this count further afield to people such as the 'Artistic Director' of Documenta 11, Okwui Enwezor, who was also inextricably linked to the project, we can see the disparate worlds that Hirschhorn attempted to bring together through this work.

The success of the Bataille Monument is debatable. There was a lot of criticism of Hirschhorn's situation of the Monument within the Turkish community, and also the employment of local people to assist in the build. Carlos Basualdo writes that critics referred to the work as abusive to, and exhibitionistic of, the people of Kassel (2004: 96-108). Interestingly, Hirschhorn's response to these accusations was that he did not wish to exclude anyone from his audience (Buchloh 2005: 86). One could question how abusive the employment of workers to assist on a creative project was? We know that Hirschhorn paid his workers eight euros per hour, which one assumes would be the equivalent to the minimum wage. Hirschhorn lived on the estate for the duration of the project as he wished to be a part of the community for the time that he worked there, rather than to be an artist who entered their social space everyday and left again. He also understood that, in order to facilitate an engagement with the local community, he had to put the work in with the local participants. This was not without problems. Whilst living on the estate, Hirschhorn's flat was broken into and expensive equipment was stolen. However, he did not go to the police but publicly asked that the equipment be returned, which it was. Because of this incident, Hirschhorn felt, in some ways, that the local inhabitants of the estate had accepted him.

Hirschhorn conforms to aspects of Boltanski and Chiapello's 'great man' in the projective city. They state:

Far from being attached to an occupation or clinging to a qualification, the great man proves adaptable and flexible, able to switch from one situation to a very different one, and adjust to it; and versatile, capable of changing activity or tools, depending on the nature of the relationship entered into with others or with objects.

([1999] 2007: 112, original emphasis)

Hirschhorn operated an anti-exclusionary policy in the making of the Bataille Monument. This policy is important in responding to the criticisms that his work was exploitative, which is also one of the criticisms aimed at capitalism from the (now co-opted) artist critique. Rather than exclude the local participants, Hirschhorn invited them to assist on the project - which they mainly ran - and also paid them for their time. Hirschhorn is against calling for volunteers to assist his projects, the use of which he considers to be exploitative. So who is being exclusionary in this equation? Is it Hirschhorn who wishes to include everyone, or the critics who see his work as exploitative because it utilized non-art workers? Boltanski and Chiapello state that the great man in the projective city is a risk taker, who must possess intuition and talent (in the artistic sense of the term) (Boltanski and Chiapello 2007: 112). 
To be excluded from the project is 'death in a reticular universe' (Boltanski and Chiapello [1999] 2007: 111).

The participants in Bataille Monument had more control over the direction of the work because of Hirschhorn's role as project manager (akin to the great man in the project-based community). The result of his work was to engage people and to facilitate discussion, while Hirschhorn stepped back. Again, we can draw correlations between new forms of management and Hirschhorn's approach. The DCMS report states: 'Over-centralisation of decision-making, while preventing deadlock, militates against organisational creativity' (The Work Foundation 2007: 142). The report further stresses the importance of 'more discursive, open-ended inquiry, the lifeblood of more radical and unexpected innovation' (The Work Foundation 2007: 142). Hirschhorn allowed for the participants to attain the results, whatever form these may take and, according to the literature, this freedom is precisely the role that the project manager should take in order to achieve truly creative, innovative results.

Claire Bishop is correct to articulate that there are aspects of Hirschhorn's work that are antagonistic, such as the choice of location, in the sense that Hirschhorn selected a site where 'friction and engagement might be possible' (Bishop 2004: 135). This selection played with the ambiguity that Hirschhorn evokes through his work, which is never quite social work (and does not intend to be); neither is it openly political. However, there is usually a definite political air around his work, and Hirschhorn is not apologetic for this ambiguity. He states:

I am the artist, and when I work in an open space I decide where to place my work. It interests me that my work has to defend itself in any surroundings, in any sector, and fight for its autonomy.

(Buchloh 2005: 86)

It is this concept of autonomy that is important for Hirschhorn, and he still considers himself to be the artist at the heart of the project: 'That is why I said that my presence on the site was not required for communication or discussion with people, but simply in the role of a caretaker, to check that everything was functioning' (Buchloh 2005: 87). Furthermore, this autonomy is rooted in the artist model on which the artist critique is based, one that demands the freedom of man from the constraints of the market. Can we understand Hirschhorn's practice as adopting the traits of the artist critique?

His role is more of the project manager - the instigator and facilitator rather than mere caretaker, which implies a kind of 'nannying'. Noticeably, Hirschhorn chooses to step back from the participants in order for 'real' experiences and discussions to take place, as opposed to ones directed by the artist. Hirschhorn's decision to avoid directing the relations between participants can be viewed as contrary to the interaction that is encouraged (or directed) by relational artists whose work engages the audience within the gallery space, such as Rirkrit Tiravanija. Although Tiravanija cooks for his audience ( $P a d$ Thai, 1990) - which then facilitates the sitting and eating with the artist or strangers - these relations occur between art gallery visitors who arguably have art in common. The cooking of food is a precursor to the sitting and eating and can be seen as 'directing' in a performative sense. The 'project', in this work, is orchestrated between participants with commonalities and, perhaps, similar educational and economic backgrounds. In contrast, Hirschhorn's snack bar was run by a local family and was frequented, not only by Documenta 11 visitors, but also people from the surrounding communities. 
The resulting conversations and interactions would perhaps be more interesting than those solely between a typical art audience. Perhaps this interpretation is a little too utopic; participants may have remained in their social groups whilst eating, as one may experience in a cafe or restaurant.

Boltanski and Chiapello state: 'The great man in a connexionist world is active and autonomous' (Boltanski and Chiapello [1999] 2007: 112). Hirschhorn sees his monuments as collaborative, but ultimately retains his name as the 'author' of the work. More pertinent, perhaps, is that he wishes art itself to remain autonomous and, therefore, as distinct from the capitalist world and the social relations that it encourages:

The other possibility is that by letting this autonomy shine through, by holding fast to this affirmation of art, I want people to reflect, to think, okay? That is what I want: reflection about my work, art in general, the passage of time, the world, reality. It is possible, for example, to talk with Turkish kids about art, because I don't talk with them as a social worker but as an artist, as someone who believes in art [...] I am not here to rehabilitate anyone, or not to rehabilitate them. That is not my job [...] At the same time I find a cynical stance impossible, because it creates no autonomy or activity for me.

(Buchloh 2005: 87-88)

Hirschhorn's method of working, with his monuments at least, is a result of the conditions of capitalism under which artists work today. The autonomy of the individual artist is not compromised because the project is subsumed under his name. Further, the mode in which he chooses to work - the collaborative project, which focuses on participation rather than object production - is in keeping with contemporaneous business working models. Thus, the emphasis on the individual under neo-liberalist ideology materializes in the 'great man' who is able to work with others but who is, ultimately, autonomous. Hirschhorn defends the autonomy of art, in which he believes anything is possible, whilst engaging in non-exclusionary collaborations. He states: 'Nothing is impossible with art. Nothing' (Buchloh 2005: 87). Moreover, Hirschhorn is, as Basualdo proposes, a modernist at heart (Basualdo 2004: 96). However, his modernist leanings lie in the type of artist that he embodies rather than how he goes about making art (the modernist artist is historically associated with painting as opposed to social engagement). This type of artist is that of the Romantic conception, which Boltanski and Chiapello argue is co-opted by capitalism, evidenced in the corpora of management literature that they examined from the 1990s. In this role, the artist is considered to be a free, creative individual, autonomous and flexible.

\section{ConClusion}

In this article, I have shown how ideological traits, identified by Boltanski and Chiapello as stemming from 1990s management literature and the co-option of the artist critique, are implicitly connected to the establishment of a neoliberal economy. This economy is based upon creativity, flexibility, short-term projects and the establishment of networks, all of which can be tied to certain conceptions of artistic production. The establishment of the Creative Industries in 1990s Britain further demonstrates the appeal of the 'creative type' to an economy based upon the aforementioned principles. Through adopting 
a Marxian understanding of ideology as connected to the economic base, I have argued that these principles are not disassociated from the production of contemporary art through an exploration of the Bataille Monument.

Hirschhorn acts as a kind of project manager in order for the creative, informational and social aspect of his art to play out. Hirschhorn may be able to initiate and implement a project, but the aims and objectives are not set in stone beforehand, and the 'result' is not predefined. What is important for Hirschhorn is the inclusionary aspect of his projects: 'I want people to be inside my work, and I want spectators to be a part of this world surrounding them in this moment' (Buchloh 2005: 95, original emphasis). Unlike the adaptable 'great man', in public works such as Bataille Monument, Hirschhorn always sees his role as that of the artist. Hirschhorn's works are, ultimately, concerned with making art and the possibilities that art can achieve. Contrary to his artistic intention, I argue that Hirschhorn still proves adaptable. He was, like the 'great man', happy to move to Kassel for the duration of his project. He lived onsite and adapted to the conditions in order to truly engage with his location and the locals that lived and worked alongside him. He also overcame the difficulties that accompanied this move, such as the earlier noted burglary. His interventions into public space are not easy transitions. He has to develop the skills to work alongside people from diverse backgrounds, the success of which he does not judge. ${ }^{9}$

Hirschhorn prioritizes experience over results. Whilst his work may be ideologically affected by working under neo-liberalism, Hirschhorn's practice is demonstrative of the fact that the artist and the neo-liberal model of manager cannot truly be assimilated. Despite Hirschhorn's practice being indebted to neo-liberal working tropes - such as the project - he will never become the 'true' manager. Contrary to the DCMS's tolerant approach to 'creatives' in order to receive economic 'payoffs', Hirschhorn's primary concern lies not with profit (the driving force of capitalism) but the experience. Boltanski and Chiapello state: 'Anything can attain the status of a project, including ventures hostile to capitalism' ([1999] 2007: 110). We see this at play in the work of Hirschhorn.

\section{referenCes}

Auston, Rob and Devin, Lee (2003), Artful Making: What Managers Need to Know About How Artists Work, New Jersey: Financial Times Prentice Hall.

Basualdo, Carlos (2004), 'Bataille Monument, Documenta 11, 2002', in B. H. D. Buchloh (ed), Thomas Hirschhorn, London: Phaidon, pp. 94-109.

Bishop, Claire (2004), 'Antagonism and relational aesthetics', October, 110: Fall, pp. 51-79.

Boltanski, Luc and Chiapello, Eve ([1999] 2007), The New Spirit of Capitalism, London: Verso.

Boltanski, Luc, and Thévenot, Laurent (1991), De la justification: les économies de la grandeur, Paris: Gallimard

Bourriaud, Nicolas (2002), Relational Aesthetics, Paris: Les presses du reel.

Buchloh, Benjamin H. D. (2005), 'An interview with Thomas Hirschhorn', October, 113: Summer, pp. 77-100.

Callinicos, Alex (2006), The Resources of Critique, Cambridge: Polity.

Chiapello, Eve (2004), 'Evolution and co-optation: The "Artist Critique" of management and capitalism', Third Text, 18: 6, pp. 585-94.

Doogan, Kevin (2009), New Capitalism? The Transformation of Work, Cambridge, Malden: Polity.
9. Hirschhorn states:

Visitors often asked me how the project was received by the residents of the housing complex. I am certainly the last person who could answer that question! It seems obvious that an answer would involve a value judgment. That would mean that if the project was received well it was a success and if not, then it was a failure. The Bataille Monument project was not a matter of acceptance or rejection. ..

(2004: 145) 
Florida, Richard (2002), The Rise of the Creative Class and How it's Transforming Work, Leisure, Community and Everyday Life, New York: Basic Books.

Graña, César (1964), Bohemian Versus Bourgeois. French Society and the French Man of Letters in the Nineteenth Century, New York: Basic Books.

Harvey, David ([1990] 2008), The Condition of Postmodernity: An Enquiry into the Origins of Cultural Change, Oxford: Blackwell.

Hirschhorn, Thomas (2004), 'Bataille Monument', in C. Doherty (ed.), Contemporary Art: From Studio to Situation, London: Black Dog, pp. 133-47.

Holmes, Brian (2004a), 'The flexible personality: For a new cultural critique', www.noemalab.org/sections/ideas/ideas_articles/pdf/holmes_flexible_ p.pdf. Accessed 14 May 2008.

- - (2004b), 'Artistic autonomy and the communication society', Third Text, 18: 6, pp. 547-55.

Lacy, Suzanne (1995), Mapping the Terrain: New Genre Public Art, Seattle: Bay Press.

Lazzarato, Maurizio (1996), 'Immaterial labour', in P. Virno and M. Hardt (eds), Radical Thought in Italy: A Potential Politics, Minneapolis: Minnesota, pp. 133-47.

- - (2007), "The misfortunes of the "Artistic Critique" and of cultural employment', http://eipcp.net/transversal/0207/lazzarato/en. Accessed 18 January 2010.

Lind, Maria (2007), 'The collaborative turn', in Johanna Billing, Maria Lind and Lars Nilsson (eds), Taking the Matter into Common Hands, London: Black Dog, pp. 15-31.

Lloyd, Richard (2006), Neo-Bohemia: Art and Commerce in the Postindustrial City, New York and Oxon: Routledge.

Marx, Karl ([1935] 2007), 'Preface to A Critique of Political Economy', in David McClellan (ed.), Karl Marx: Selected Writings, Oxford: Oxford University Press, pp. 424-28.

The Work Foundation (2007), 'Staying ahead: The economic performance of the UK's Creative Industries', http://www.theworkfoundation.com/assets/ docs/publications/176_stayingahead.pdf. Accessed 18 January 2010.

\section{SuggeSted citation}

Child, D. (2012), 'The artist as project manager: Thomas Hirschhorn's Bataille Monument (2002)', Journal of Arts E Communities 4: 3, pp. 217-230, doi: 10.1386/jaac.4.3.217_1

\section{contributor details}

Danielle Child is Lecturer in Contemporary Art History at Manchester Metropolitan University. Her 2011 Ph.D. thesis is titled 'Socialised labour under change: Collaboration, contracted labour and collective modes of production in art since the 1960s'. Her current work examines the role of art-activism under neo-liberalism.

Contact: G15 Grosvenor Building, Manchester Metropolitan University, All Saints, Manchester, M15 6BR, UK.

E-mail: dlchild2002@yahoo.co.uk

Danielle Child has asserted her right under the Copyright, Designs and Patents Act, 1988, to be identified as the author of this work in the format that was submitted to Intellect Ltd. 